Regional and Business Studies (2018) Vol 10 No 1, 1-11

Kaposvár University, Faculty of Economic Science, Kaposvár

doi: $10.33568 /$ rbs.2331

\title{
ENTERPRISES IN VIETNAM: THE IMPLEMENTATION OF CSR
}

\author{
Van-Thanh PHAN ${ }^{1,2}$, Szilárd PodruzsIK ${ }^{3}$ \\ ${ }^{1}$ Kaposvár University, Faculty of Economic Science, H-7400 Kaposvár Guba S. u. 40. \\ ${ }^{2}$ Hanoi University of Science and Technology, VN-100000 HaNoi, Dai Co Viet Road 1. \\ ${ }^{3}$ Corvinus University of Budapest, H-1093 Budapest, Fővám tér 8.
}

\begin{abstract}
Corporate social responsibility (CSR) has become a prominent issue for long-term sustainability, and several enterprises have come to recognize it as a key factor in their success. Organizations that participate in CSR activities construct purchaser trust and pass on a positive organization image. However, CSR activities, up to now, have been in general spotlight chiefly at large and multinational organizations. Under pressures from the society, large companies have integrated CSR either into their short or long-term business strategy in. Similarly, in Vietnam, which is a developing country, numerous huge undertakings know that with the end goal to grow economically, enterprises must conform to ecological assurance norms, indiscrimination policy, work rights, work security, equal pay, ability to advance .the board and network 97 percent, the majority of enrolled ventures are small and medium enterprises (SMEs). The execution and use of CSR in Vietnamese SMEs confront a lot of troubles and restrictions because of constrained monetary assets, personnel, size of the companies, in most cases the owner is also the director. Therefore, the main purpose of this article is to investigate the practice of CSR in Vietnamese enterprises. Also, the article collates the recommendations given by researchers in order to strengthen and improve the implementation of CSR in Vietnam as well as gives some recommendations to help Vietnamese enterprises get success in applying CSR in their sustainable business objectives. The findings of this study are important to Vietnamese enterprises and future researchers in CSR in Vietnam in particular.
\end{abstract}

Keywords: Corporate Social Responsibility, CSR, Vietnamese Enterprises, Vietnam

\section{INTRODUCTION}

Corporate social responsibility (CSR) has turned into a noticeable issue for long-haul supportability, and numerous ventures have come to remember it as a key factor in their prosperity. Companies that engage in CSR initiatives build consumer trust and convey a positive company image. However, CSR initiatives, have tended to focus mainly on large and multinational companies so far. Under pressure from the society, substantial organizations have incorporated CSR in their business technique either in a short or a long-term system. They actualized several activities, for example sparing vitality, utilizing reused materials, lessening carbon outflows, or some gift, like school building, help victims of catastrophic events. There are some ongoing CSR activities, such as Pratham Books (Creating an open-sourced platform for translating books); and Give Directly (Creating opportunity through mobile cash transfers) implemented 
by Google's Since 2006, Microsoft Corporation has had a formal promise to regard human rights as a signatory of the United Nations Global Compact.

In Vietnam, according to the report of the Asian Development Bank, Vietnamese SMEs play an essential role in the national economy. They account for 77.3 percent of the country's total labour force and contribute 26 percent of Vietnam's GDP (Shinozaki, 2012). Furthermore, recent researches have concluded that CSR brings benefits both to business and society, both large and SMEs (Udayasankar, 2007). According to Lee, Park, and Lee, CSR capabilities are characterized as an organization's knowledge, abilities, and procedures related to the arranging, execution, and assessment of CSR activities (Lee et al., 2013). Such CSR abilities could be a standout amongst the most essential vital methodologies in an organization's CSR endeavours. CSR helps to improve the image and reputation of the business; increase sale volumes; increase employee motivation, increase attractiveness to potential recruits, etc. (Jenkins, 2006; Dzansi, 2011).

In order to achieve the objective of sustainable development, Vietnamese enterprises are not only complying with government mandated standards of employment, environment, and society, but also deal actively with social responsibility which is not regulated by law. Because of early perceptions, several large enterprises in Vietnam have put CSR on the top priority to integrate into their business strategy. Similarly, Vietnamese SMEs also have to develop and integrate CSR into their business strategy. However, awareness of CSR and their CSR activities are inadequate. Therefore, the main purpose of this paper is to give a descriptive analysis of the practices of CSR in Vietnam, especially in Vietnamese SMEs based on available literature and published data.

In the next sections, the authors review the concept of Vietnamese enterprises and their current situation. Then they review the updated concept of CSR in the world in general and in Vietnam in particular. Finally, the paper provides a descriptive analysis of CSR practices in Vietnamese enterprises and highlights some recommendations to help Vietnamese enterprises succeed in applying CSR into their business strategy.

\section{VIETNAMESE ENTERPRISES}

In Vietnam, according to Article 6 of the Vietnamese Government's Decree No. 39/2018/ND-CP, "SMEs are business establishments registered in accordance with the law. It is divided into three levels: micro, small and medium scale (the total capital equivalent to the total assets determined in the enterprise's balance sheet or the average labour force is a priority criterion)" (Table 1).

Indeed, SMEs include an extremely expansive scope of endeavors from built up customary privately-run company utilizing over a hundred people to independently employed individuals working in casual microenterprises. In 2012, Vietnamese SMEs accounted for 77.3 percent of the country's total labour force and contributed 26 percent to Vietnam's GDP (Shinozaki, 2012). Moreover, most of them are micro enterprises (Figure 1), and this number increased on average by 14 percent annually from 2011 to 2016 (Figure 2). 


\section{Table 1}

\section{SME criteria by Vietnamese Government's Decree No. 39/2018/ND-CP}

\begin{tabular}{|l|c|c|c|c|c|c|}
\hline \multirow{2}{*}{ Business sector } & \multicolumn{7}{|c|}{ Micro } & \multicolumn{2}{c|}{ Small } & \multicolumn{2}{c|}{ Medium-sized } \\
\cline { 2 - 7 } & $\begin{array}{c}\mathrm{A} \text { and R* } \\
\text { (Bil. VND) }\end{array}$ & $\begin{array}{c}\text { Number of } \\
\text { employees (L) }\end{array}$ & $\begin{array}{c}\mathrm{A} \text { and R } \\
\text { (Bil. VND) }\end{array}$ & $\begin{array}{c}\text { Number of } \\
\text { employees (L) }\end{array}$ & $\begin{array}{c}\mathrm{A} \text { and R } \\
\text { (Bil. VND) }\end{array}$ & $\begin{array}{c}\text { Number of } \\
\text { employees (L) }\end{array}$ \\
\hline $\begin{array}{l}\text { I. Agriculture, } \\
\text { forestry and } \\
\text { fisheries }\end{array}$ & $\begin{array}{c}\mathrm{A} \leq 3 \\
\text { or } \mathrm{R} \leq 3\end{array}$ & $\mathrm{~L} \leq 10$ & $\begin{array}{c}\mathrm{A} \leq 20 \\
\text { or } \mathrm{R} \leq 50\end{array}$ & $10<\mathrm{L} \leq 100$ & $\begin{array}{c}\mathrm{A} \leq 100 \\
\text { or } \mathrm{R} \leq 200\end{array}$ & $100<\mathrm{L} \leq 200$ \\
\hline $\begin{array}{l}\text { II. Industry and } \\
\text { construction }\end{array}$ & $\begin{array}{c}\mathrm{A} \leq 3 \\
\text { or } \mathrm{R} \leq 3\end{array}$ & $\mathrm{~L} \leq 10$ & $\begin{array}{c}\mathrm{A} \leq 20 \\
\text { or } \mathrm{R} \leq 50\end{array}$ & $10<\mathrm{L} \leq 100$ & $\begin{array}{c}\mathrm{A} \leq 100 \\
\text { or } \mathrm{R} \leq 200\end{array}$ & $100<\mathrm{L} \leq 200$ \\
\hline $\begin{array}{l}\text { III. Trade and } \\
\text { services }\end{array}$ & $\begin{array}{c}\mathrm{A} \leq 3 \\
\text { or } \mathrm{R} \leq 10\end{array}$ & $\mathrm{~L} \leq 10$ & $\begin{array}{c}\mathrm{A} \leq 50 \\
\text { or } \mathrm{R} \leq 100\end{array}$ & $10<\mathrm{L} \leq 50$ & $\begin{array}{c}\mathrm{A} \leq 100 \\
\text { or } \mathrm{R} \leq 300\end{array}$ & $50<\mathrm{L} \leq 100$ \\
\hline
\end{tabular}

Source: Summary from Vietnamese Government's Decree No. 39/2018/ND-CP

* A: Total assets (Bil. VND); R: Total revenue of the year (Bil. VND) L: The average number of employees participating in social insurance of the year.

Figure 1

Breakdown of Vietnamese SMEs in 2016 (Can, 2017)

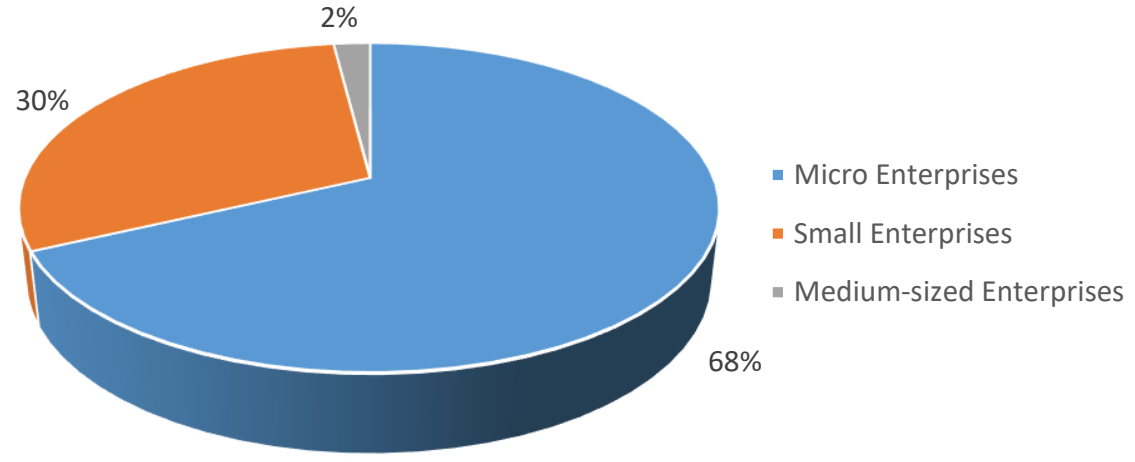

Furthermore, in a recent survey conducted by CPA Australia, the institute reported that 90.7 percent of Vietnamese SMEs grew in 2017 and 93.7 percent is expect to grow in the next 12 months. At the same time only 47.5 percent of Singapore's small businesses reported that they grew in 2017, and 93.4 percent of Indonesian small businesses reported that they grew. These figures partly explain the importance of SMEs to Vietnam's economic development, and the growing interest of domestic and foreign researchers in Vietnamese SMEs as well (CPA Australia, 2018).

In addition, recent studies have indicated that SMEs are playing a vital role in national economy, especially in Vietnamese economy. CSR is considered to be a decisive factor for supportable development and expanded gainfulness, and CSR 
brings benefits both to business and society, to both large and SMEs (Udayasankar, 2007). The advantages of executing CSR in SMEs include: enhanced picture and notoriety; enhanced trust and comprehension; bigger, more conspicuous profile; better market position; expanded deal volumes; expanded employer inspiration; expanded appeal to potential enlisted people; cost investment funds and expanded productivity; upgraded chance administration; benefits for organization culture; improved consumer loyalty, representative faithfulness, and so on. (Jenkins, 2006) and (Dransi, 2011).

\section{Figure 2}

\section{Number of newly registered enterprises from 2011-2016 in Vietnam}

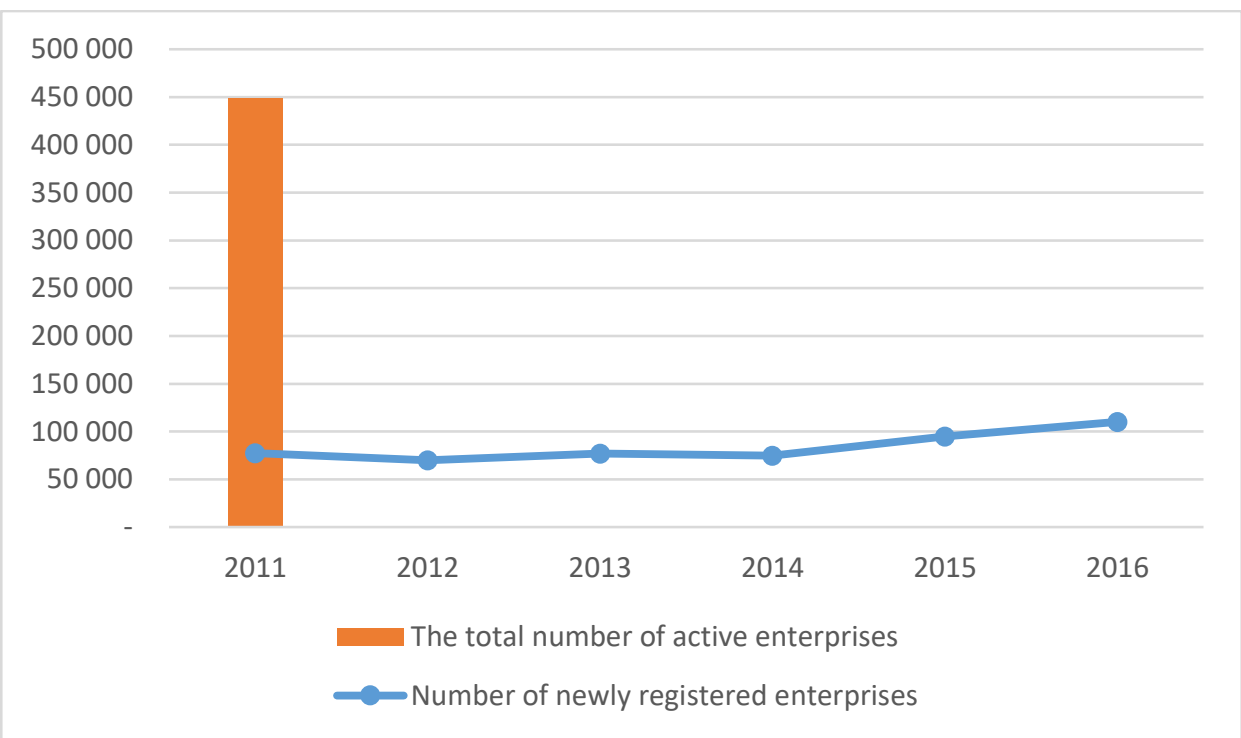

Source: http://www.gso.gov.vn

Hence, this paper focuses on Vietnamese SMEs and presents the practice of CSR in Vietnamese SMEs in particular and Vietnamese enterprises in general. In the next sections, we will briefly review CSR concepts, then focus on the implementation of CSR in Vietnam as well as give some recommendations to help Vietnamese enterprises get success by applying CSR in their sustainable business objectives.

\section{CORPORATE SOCIAL RESPONSIBILITY}

Despite more than 60 years of history, the concept of CSR is still unpredictable and entangled. It is unpredictable not just regarding the nature and setting of the issues, yet it is likewise muddled by four unmistakable motivations which is occupied with the definitional endeavour (Sheeby, 2015). Numerous attempts can be identified in literature to define CSR. Various reviews of CSR definition were published over the 
last decade, including Carroll (2009), Dablsrud (2008), Kraus and Brtitzelmaier (2012), Madrakhimova (2013) and Sheehy (2015). However, the authors have not reached a consensus about CSR definition, as CSR varies in context, content, process, and value. The early definition of CSR is more often referred to social responsibility (SR) than to CSR, "It refers to the obligations of businessmen to pursue those policies, to make those decisions, or to follow those lines of action which are desirable in terms of the objectives and values of our society" (Bowen, 1953). In 1979, Archie Carroll proposed a four-part definition of CSR: "The social responsibility of business encompasses the economic, legal, ethical and discretionary expectations that society has of organization at a given point in time" (Carroll, 1979). The pyramid of CSR that was introduced by Carroll in 1991 is one of the earliest attempts to integrate the economic and social responsibilities of the corporation.

According to Dablsrud, CSR definitions could be categorized by five dimensions, including Environmental; Social; Economic; Stakeholder; and Voluntariness (Dablsrud, 2008). Dahlsrud also pointed to the definition of CSR with the highest frequency counts from Google to the Commission of the European Communities, which defined CSR as "A concept whereby companies integrate social and environmental concerns in their business operations and in their interaction with their stakeholders on a voluntary basis" (European Commission, 2002). Besides this definition, there are other definitions referring to five dimensions of CSR, which were defined by Business for Social Responsibility in 2000 and 2003; International Business Leaders Forum (IBLF) in 2003; Global Corporate Social Responsibility Policies Project in 2003; UK Government in 2001; and $V$ an Marrewijk in 2003. The rest of the 37 analytical definitions in Dahlsrud's study refer to four, three, two or even just one dimensions of CSR. However, in the recent review article, Wang and Gao summarized the definition of CSR according to four common perspectives, including: (1) an integrative perspective, namely, those definitions generated from a spectrum of views ranging from stakeholder concerns to social issues; (2) an economic perspective, supported by those researchers who believe that the aim of CSR activities is the maximization of profit, which emphasizes the benefits to shareholders and internal stakeholders; (3) a voluntary perspective, supported by those researchers who believe that firms should take some philanthropic action in accordance with local laws to improve social welfare; and (4) a public perspective, where scholars argue that a CSR strategy should be designed to fit in the social system ( $W$ ang and Gao, 2016).

Thus, it can be stated that CSR is more than charity and philanthropy. CSR is the commitment of enterprises to integrate social and environmental responsibility in their business operations to improve the quality of life of the stakeholders. CSR is "the continuing commitment by business to contribute to the economic development while improving the quality of life of the workforce and their families as well as of the community and society at large" (WBSCD, 2000). CSR is about creating business and social value, about aligning and balancing shareholder, about societal and environmental interests. CSR is defined as the way through which a company achieves a balance of economic, environmental and social imperatives, while at the same time addresses the expectation of shareholders and stakeholders (UNIDO, 2010). An effective CSR strategy balances the interests of shareholders, society, and the planet, making businesses stronger and more sustainable. 
In Vietnam, in spite of the fact that there is great interest in the concept of CSR in the world, there are limited theoretical or empirical contributions to CSR to date. According to Nguyen Ngoc Mai, CSR is understood as the enterprise commitments to add to the sustainable economic improvement, through enhancing living nature of workers, of their own families, of the network and of the entire society, in the manner in which is advantageous to both the ventures and the general advancement of the general public (Nguyen, 2013). Furthermore, in the context of globalization and international integration, Vietnamese companies will not be able to gain access to the international market if the companies fail to implement their social responsibility effectively. For the purpose of sustainable development, companies must comply with environmental protection standards, gender equality, labour safety, labour rights, equal pay, staff training and community development. Therefore, the implementation of CSR has become one of the essential requirements of Vietnamese companies.

\section{THE IMPLEMENTATION OF CSR IN VIETNAM}

Based on the figures, the articles, as well as research reports of NGOs, are published it can be concluded that here are three important points in the history of CSR in Vietnam. Firstly, in the 2000s CSR was introduced in Vietnam through the operation of the multinational companies investing in Vietnam. Secondly, in 2005, the CSR Awards began to be given to the most committed businesses by the Vietnam Business Linking Initiative (VBLI), established with the support of the Vietnam Chamber of Commerce and Industry (VCCI). Thirdly, in 2010, Vietnam received the EU-funded project "Helping Vietnamese SMEs Adapt \& Adopt CSR for Improved Linkages with Global Supply Chains in Sustainable", implemented in Vietnam by the United Nations Industrial Development Organization (UNIDO) from 2010 to 2013, which marked the change in awareness of Vietnamese enterprises, especially Vietnamese SMEs.

In the 2000s, with the investment in Vietnam, multinational companies such as Honda, Toyota, Coca-Cola Vietnam, Unilever-Vietnam, Microsoft, HP, brought the concept of CSR into Vietnam. These companies commonly develop the Code of Conduct $(\mathrm{CoC})$ and standards of business culture which are universal in order to be applicable in various geographical markets (Ngyyen et al., 2015). A number of successful CSR programs at that time were launched, such as "I love Vietnam" program of Honda Vietnam in 2004; Vision rehabilitation program for poor children of Western Union in 2004; Coca-Cola Vietnam began the Clean Water for Communities project in 2006. Unilever-Vietnam began the Protection Vietnamese Smile program in 1998, Sanitation program for children in mountainous provinces in 2007; Program for the Development of Sustainable Community Informatics Centers in 64 Provinces of Vietnam (TOPIC64), sponsored by Microsoft, Qualcomm, Hewlett Packard and USAID from 2006; The program supports congenital malformations and gives support for victims of Can Tho bridge collapse of VinaCapital and Samsung in 2007.

In 2005, the Vietnamese government also started to encourage companies to protect the environment and improve working conditions. They issued new rules for sustainable development, examples of this are Agenda 21 and the new Law of 
Environmental Protection. Environmental police have been set up to take measures to stop polluting companies, and companies will be subject to separate penalties for contaminated sewage. With the support of VCCI, VBLI has established a close relationships with NGOs, other international organizations as well as businesses using foreign capital. SMEs shoe manufacturers and industrial textiles can participate in training programs or consultancy services provided by the VBLI to improve the working environment as well as to enhance awareness of CSR. In 2005, VBLI also started giving "CSR Awards" to the most committed businesses. Some typical programs were for example "P/S protect Vietnamese smile" program of UnileverVietnam; "6 million glasses of milk for Vietnamese children" program implemented by Vinamilk; Scholarship fund "firefly lights" established by a Dutch Lady.

2010 marked the change in awareness of Vietnamese SMEs, due to the fact that EU funding project entitled "Helping Vietnamese SMEs Adapt and Adopt CSR for Improved Linkages with Global Supply Chains in Sustainable” had been implemented in Vietnam by the UNIDO since 2009. Thanks to this project, many SMEs in Vietnam were trained and they updated their CSR knowledge through training sessions or seminars. According to the surveys that were conducted by Taylor Nelson Sofres Viet Nam in 2013, it can be concluded that there is clear evidence of increased awareness about the understanding and practice of CSR in the sector of SMEs within the time period of the UNIDO's project in Vietnam (Table 2) (UNIDO, 2013).

\section{Table 2}

\section{CSR awareness score distribution of Vietnamese SMEs}

\begin{tabular}{|l|c|c|c|c|c|c|c|c|}
\hline \multirow{2}{*}{$\begin{array}{c}\text { Range of } \\
\text { Awareness } \\
\text { Score } *\end{array}$} & \multicolumn{2}{|c|}{ Total } & \multicolumn{2}{c|}{$\begin{array}{c}\text { Textiles and } \\
\text { garment }\end{array}$} & \multicolumn{2}{c|}{$\begin{array}{c}\text { Leather and } \\
\text { footwear }\end{array}$} & \multicolumn{2}{c|}{ Electronics } \\
\cline { 2 - 9 } & Baseline & End-line & Baseline & End-line & Baseline & End-line & Baseline & End-line \\
\cline { 2 - 9 } & $(\mathrm{n}=400)$ & $(\mathrm{n}=400)$ & $(\mathrm{n}=192)$ & $(\mathrm{n}=199)$ & $(\mathrm{n}=185)$ & $(\mathrm{n}=160)$ & $(\mathrm{n}=50)$ & $(\mathrm{n}=41)$ \\
\hline $\mathbf{1 0}$ & 0.3 & 0 & 0 & 0 & 0.6 & 0 & 0 & 0 \\
\hline $\mathbf{1 1}$ to $\mathbf{2 0}$ & 0.6 & 0 & 0.5 & 0 & 0.6 & 0 & 0 & 0 \\
\hline $\mathbf{2 1}$ to $\mathbf{3 0}$ & 3.7 & 2.9 & 4.1 & 2.5 & 3.1 & 2.4 & 2 & 2.4 \\
\hline $\mathbf{3 1}$ to $\mathbf{4 0}$ & 14.8 & 17.8 & 16.8 & 18.5 & 14 & 17 & 8 & 14.6 \\
\hline $\mathbf{4 1}$ to $\mathbf{5 0}$ & 53.3 & 60.1 & 50.7 & 56 & 53.8 & 64.5 & 60 & 58.6 \\
\hline $\begin{array}{l}\mathbf{5 1} \text { to } \\
\text { highest }\end{array}$ & 28.4 & 20.5 & 28 & 22.5 & 27.6 & 16.4 & 30 & 24.3 \\
\hline
\end{tabular}

Source: UNIDO, 2013

* The higher scores show the higher awareness of CSR. Scores based on the answers (corresponds to values from 0 to 3) that each respondent gave to each statement. Each respondent could get a score between 0 (if a respondent said that all 20 statements were not at all important) and 60 (if a respondent said that all 20 statements were very important); "Baseline" and "End-line" refer to the year when the survey was conducted on the similar sample of 400 SMEs, in 2009 and 2013, respectively.

In another research conducted by the World Bank in Vietnam, the biggest barriers and challenges of the implementation of CSR of enterprises are: Insufficient awareness of the concept of social responsibility within and between corporates in Vietnam; Productivity being affected when performing multiple sets of Codes of 
Conduct synchronously; Lack of financial and technical resources for the implementation of social responsibility standards (especially for SMEs); Confusion for corporates due to differences between Code of Conduct and the Labour Code; CSR activities that have been implemented without transparency are hindering benefits brought by potential markets to businesses; State's regulations affect the results of the implementation of the code of conduct; and The habits in consumer culture have not promoted the role of customers in protecting products of corporates that have well implemented social responsibility as well as the fighting spirit against corporate with commercial frauds.

Therefore, it can be asserted that enterprises in Vietnam today which have integrated CSR into their business strategy regularly are multinational, big enterprises and the enterprises with export market. Meanwhile, many SMEs in Vietnam are not fully aware of CSR, not aware of the benefits and opportunities that CSR can bring to the business. They frequently focus only on exploiting the resources available to maximize profits but forget the interests of customers, the responsibility to labourers, to the eco-environment, to the community and to the future generations (Nguyen et al., 2015). Social activities, if any, are only charitable activities for some individuals and/or communities where the business operates. In fact, besides the "good programs" as mentioned above, there have been many "bad activities" - cases of business ethics violations, serious environmental and human health violations. For example, the most serious recent incident has been the Vietnam sea catastrophe in 2016, which was a water pollution crisis that $\mathrm{s}$ affected the central provinces of Vietnam - The Formosa steel plant was associated to be the source with the lethal synthetic waste; or some typical incidents happened in the past, such as milk containing birth control drug, melamine of China; industrial alcohol made fatal to consumers; poor quality counterfeit fertilizers; soya source containing 3-MCPD; growth stimulators passed on cattle through animal feed not fully resolved; direct discharge of untreated sewage into Vedan's Thi Vai River in Vietnam... This is due to the lack of a sense of corporate social responsibility that has serious consequences for the environment, society and the consumers (Nguyen and Luu, 2008).

In addition, due to the lack of social responsibility regulations from the government, the Vietnamese mechanisms and punishments are not sufficient to prevent enterprises from violating the law, and as a result, many enterprises do not care about these lawsuits. There have been many cases of violations that have been identified but also difficult to resolve, such as the controversy over the sanctioning form of Vedan in 2008 or the recent case of Formosa Ha Tinh in 2016 (Phan and Podruzsik, 2017). Similarly, in October 2008, Vinh Long province detected 11 companies producing poor quality fertilizers, of which the useful ingredient was almost zero. However, these companies were fined only a total of VND 130 million. Clearly, fines are too small compared to the profits earned from fraud, as well as its impact on farmers.

\section{CONCLUSION}

According to recent CSR studies in Vietnam, it can be said that the implementation of CSR in Vietnam is limited. CSR activities are almost done by lager and 
international companies, not SMEs in Vietnam. There are several obstacles and limitations in implementing CSR not only due to the business itself, but also the operating environment.

Awareness of CSR in some Vietnamese SME sectors increased from 2010 to 2013 (UNIDO, 2013). However, there is still limited awareness and practice of CSR in Vietnamese enterprises. Vietnamese SMEs lack budgetary and specialized assets for the usage of social duty benchmarks and focus more on augmenting benefits than on social obligation.

Besides, there are limitations of social responsibility rules from the Vietnamese government because the Vietnamese legal framework is inadequate and syndication, defilement and gathering interests intensely impact society. The Vietnamese instruments and punishments are not sufficient to prevent businesses from violating the law.

Therefore, in order to apply and integrate CSR into the Vietnamese firms' business strategies, the awareness of CSR should be enriched as well as the legal background for applying CSR. A further study could identify factors that influence Vietnamese SMEs to fulfill their social responsibilities as well as to decide the influence of CSR on the business performance of Vietnamese enterprises.

\section{REFERENCES}

Bowen, H.R. (1953): Social responsibilities of businessman. New York: Harper \& Brothers.

Can, V.L. (2017): SMEs Development: Vietnamese Experience. In: PECC Singapore Conference “APEC's Post 2020 Agenda: Rising Protectionism, Economic Rebalancing and Diversified Growth". Singapore. [online] <URL: https://www.pecc.org/resources/trade-and-investment-1/2421-smesdevelopment-vietnamese-experience/file>

Carroll, A.B. (1979): A Three-Dimensional Conceptual Model of Corporate Performance. In: Academy of Management Review, 4. 4. 497-505. p. doi: 10.5465/amr.1979.4498296

Carroll, A.B. (2009): A History of Corporate Social Responsibility: Concepts and Practices. In: The Oxford Handbook of Corporate Social Responsibility. doi: 10.1093/oxfordhb/9780199211593.003.0002

CPA Australia (2018): The CPA Australia Asia-Pacific Small Business Survey 2017. Australia: CPA Australia Ltd., 99. p. [online] <URL: https://www. cpaaustralia.com.au/-/media/corporate/allfiles/document/professionalresources/business-management/small-business-survey/small-businesssurvey-2017.pdf?la $=$ en\&rev $=5524 \mathrm{dfb} 82 \mathrm{bac} 47209 \mathrm{e} 6 \mathrm{~b} 985 \mathrm{f} 8 \mathrm{cf} 15 \mathrm{e} 7 \mathrm{e}>$

Dahlsrud, A. (2008): How Corporate Social Responsibility is Defined: An Analysis of 37 Definitions. In: Corporate Social Responsibility and Environmental Management, 15. 1., 1-13. p. doi: 10.1002/csr.132

Dzansi, D.Y. (2011): Social responsibility of small businesses in a typical rural African setting: Some insights from a South African study. In: African Journal of Business Management, 5. 14. 5710-5723. p. 
European Commission (2002): Corporate Social Responsibility: A business contribution to Sustainable Development. Brussels. 1-24. p. [online] <URL: https:/ / ec.europa.eu/europeaid/sites/devco/files/communication-corporatesocial-responsibility-sustainable-development-com2002347-20020702_en.pdf

Jenkins, H. (2006): Small business champions for corporate social responsibility. In: Journal of Business Ethics, 67. 3. 241-256. p. doi: 10.1007/s10551-006-9182-6

Kraus, P., Brtitzelmaier, B. (2012): A literature review on corporate social responsibility: definitions, theories and recent empirical research. In: International Journal of Management Cases, 14. 4. 282-296. p. doi: 10.5848/apbj.2012.00105

Lee, E.M., Park, S.Y., Lee, H.J. (2013): Employee perception of CSR activities: Its antecedents and consequences. In: Journal of Business Research, 66. 10. 17161724. p. doi: $10.1016 /$ j.jbusres.2012.11.008

Madrakhimova, F.S. (2013): Evolution of the Concept and Definition of Corporate Social Responsibility. In: Global Conference on Business and Finance Proceedings, 8. 2. 113-119. p. [online] <URL: http://home.uona.edu/ UoNA/files/literature/3229.2342_ISSN-1941-9589-V8-N2-2013_a.pdf>

Nguyen, D.C., Luu, M.D. (2008): CSR: Some of theoretical issues and requirements for state management of CSR in Vietnam. In: Economic Management Review, 23. 1-16. p.

Nguyen N.M. (2013): Understanding the social responsibility of Korean businesses in Vietnam (Part 1). In: Center for Korean Studies. [online] <URL: http://cks.inas.gov.vn/index.php? newsid=323>

Nguyen, T.-V., Mai, P.-H., Tran, P.-H., Nguyen, V.-P. (2015): Current situation of Corporate Social Responsibility in Vietnam today. In: European Journal of Business and Social Sciences, 4. 9. 156-163. p.

Phan, V.-T., Podruzsik, Sz., (2017): Corporate social responsibility in Vietnamese SMEs. In: Proceedings of the $6^{\text {th }}$ International Conference of Economic Sciences. Kaposvár University - 4-5 May 2017, Kaposvár: Kaposvár University, Faculty of Economic Science. 381-390. p.

Sheehy, B. (2015): Defining CSR: Problems and Solutions. In: Journal of Business Ethics, 131. 3. 625-648. p. doi: 10.1007/s10551-014-2281-x

Shinozaki, S. (2012): A New Regime of SME Finance in Emerging Asia: Empowering Growth-Oriented SMEs to Build Resilient National Economies. Mandaluyong: Asian Development Bank, 37. p.

Udayasankar, K. (2007): Corporate social responsibility and firm size. In: Journal of Business Ethics, 83. 2. 167-175. p. doi: 10.1007/s10551-007-9609-8

UNIDO (2010): Baseline Survey Report on Awareness, Understanding and Usage of CSR in Vietnam. Vienna: United Nations Industrial Development Organizations

UNIDO (2013): End of Action Survey: Helping Vietnamese SMEs to Adapt and Adopt CSR for Improved Linkages in Global Supply Chains in Sustainable Production. Vienna: United Nations Industrial Development Organizations

Van Marrewijk, M. (2003): Concepts and definitions of CSR and corporate sustainability: Between agency and communion. In: Journal of Business Ethics, 44. 2-3. 95-105. p. doi: 10.1023/A:1023331212247 
Wang, S., Gao, Y. (2016): What do we know about corporate social responsibility research? A content analysis. In: The Irish Journal of Management, 35. 1. 1-16. p. doi: 10.1515/ijm-2016-0001

WBSCD. (2000): Corporate Social Responsibility: Making good Business Sense. [online] <URL: http://old.wbcsd.org/pages/edocument/edocumentdetails. aspx?id $=83 \&$ nosearchcontextkey $=$ true $>$

Corresponding author:

\section{Van-Thanh PHAN}

Kaposvar University

Faculty of Economic Science

H-7400 Kaposvár, Guba Sándor u. 40.

e-mail: thanhpv.hut@gmail.com 